Osoba i doświadczenie mistyczne (4) „Filozofia Chrześcijańska” 16 (2019), s. 105-121

AGNIESZKA GOTCHOLD

Uniwersytet SWPS

\title{
O pragnieniu Prawdy. Propozycja Platona a kontekst przekazu biblijnego w świetle teorii mimetyczno-ofiarniczej René Girarda
}

Pragnienie Prawdy, jak każde pragnienie metafizyczne, jest zapożyczone. René Girard (1923-2015), francuski antropolog filozoficzny, stawia tezę, że przyczyną pragnienia i jego siłą napędową nie jest rzeczywista wartość upragnionego obiektu, lecz fakt, że jest on pożądany przez innego. Zjawisko to nazywa pragnieniem/ pożądaniem mimetycznym, gdyż wyraża ono dążenie do przywłaszczenia tego, co należy do bliźniego ${ }^{1}$. Im bardziej abstrakcyjny obiekt, tym trudniej jest wejść w jego posiadanie, a niekiedy jest ono w ogóle niemożliwe. Wartość takiego obiektu rośnie również w oczach innych osób, które przyłączają się do łańcucha osób pożądających. Konsekwencje tego zjawiska dla powstania i rozwoju kultury są dalekosiężne. Według Girarda każde zapośredniczone pragnienie prowadzi do rywalizacji, a ta z kolei do kryzysu mimetycznego - wszyscy stają się niejako sobowtórami, rywalizując o jeden $i$ ten sam obiekt. W rezultacie we wspólnocie dochodzi do wybuchu przemocy, która ostatecznie skupia się na jednej ofierze - z reguły jednogłośnie i arbitralnie wybranej. Ofiara ta jest jakoby odpowiedzialna za wszystkie możliwe nieszczęścia. W książce Początki kultury Girard wyjaśnia: „Wyrażenie «mechanizm mimetyczny» obejmuje bardzo szerokie spektrum zjawisk: oznacza cały proces, który rozpoczyna się pragnieniem mimetycznym, trwa w rywalizacji mimetycznej, dochodzi do wrzenia w kryzysie mimetycznym lub ofiarniczym

${ }^{1}$ Tłumaczenie terminu „désir mimétique” na język polski rodzi pewne trudności i stąd obecność dwóch terminów w tym kontekście, tj. pragnienia oraz pożądania mimetycznego w zależności od tłumaczenia: Por. R. Girard, Początki kultury, thum. M. Romanek, Kraków 2006, s. 61 i nn. oraz tenże, Widziatem szatana spadającego z nieba jak blyskawica, tłum. E. Buska, Warszawa 2002, s. 22 i nn. Oczywiście pragnienie i pożądanie nie są terminami tożsamymi. 
i kończy się rozwiązaniem, jakim jest kozioł ofiarny"2. To właśnie uruchomienie mechanizmu kozła ofiarnego, będącego wynikiem przemocy mimetycznej, prowadzi do zażegnania konfliktu i staje się swoistym antidotum, które kładzie, przynajmniej tymczasowo, kres przemocy. Śmierć niewinnej ofiary ofiarnicza katharsis - umożliwia przywrócenie „normalności”. Ów mord założycielski, zdaniem Girarda, leży u podstaw każdej kultury³.

Odwołując się do teorii Girarda, będę próbowała odpowiedzieć na pytanie, czym jest Platońskie pragnienie Prawdy ujęte w metaforze jaskini oraz jaki ma ono wpływ na kształtowanie się wspólnoty państwowej u Platona. Ponadto będę chciała wykazać prawdziwość zaproponowanego przez Platona mechanizmu w odniesieniu do Biblii, opierając się na analizie mechanizmu mimetycznego ujawnionego w pragnieniu Prawdy. Platon, podobnie jak Biblia, ukazuje dzieje jednostki we wspólnocie. W obu przypadkach chodzi o jednostkę wybitną - Platońskiego anaxa, starotestamentowego Mojżesza i nowotestamentowego Jezusa, o jednostkę, która poznała Prawdę. Poznanie to stanowi o jej inności i budzi nieświadomą zazdrość pozostałych członków wspólnoty, którzy z czasem nastają na jej życie. Zarówno u Platona, jak i w Starym Testamencie, nie dochodzi jednak do morderstwa, a tym samym do rozładowania przemocy w ofiarniczej katharsis. To właśnie thumiona przemoc ujawnia się u podstaw Platońskiej koncepcji państwa i starotestamentowej idei narodu wybranego i to ona kształtuje stosunki wspólnotowe w diametralnie inny sposób, niż ma to miejsce w Nowym Testamencie, gdzie przemoc mimetyczna znajduje swoje ujście w zabójstwie. Zaczynając od Platona, skupię się na analizie porównawczej zapośredniczonego pragnienia, towarzyszącej mu symboliki oraz konsekwencjach mechanizmu mimetycznego dla wspólnoty.

\section{Platon}

W księdze VII Państwa Platon posłużył się metaforą jaskini, w której znajdują się ludzie odwróceni plecami do wejścia, skąd przychodzi światło. Zniewoleni oglądają jedynie cienie prawdziwej rzeczywistości. Do pewnego momentu nie ma to dla nich jednak większego znaczenia, gdyż nie są świadomi istnienia innego świata - świata Prawdy, a więc „cienie [...] wytworów" wydają się im prawdziwe 4 . Sytuacja jednak ulega zmianie, gdy jednemu z członków wspólnoty udaje się wyswobodzić i dotrzeć do światła. Droga ta jest żmudna i spowita cierpieniem, gdyż ów człowiek, wleczony pod górę ku

2 R. Girard, Poczatki kultury, dz. cyt., s. 61 i n.

${ }^{3}$ Por. R. Girard, Widziałem szatana spadajacego z nieba jak blyskawica, dz. cyt., s. 95.

${ }^{4}$ Platon, Platona Państwo z dodatkiem siedmiu ksiag ,Praw”, t. 1, thum. W. Witwicki, Warszawa 1958 , s. 360. 
wyjściu, musi patrzeć prosto w światło, a wzrok jego nie jest do tego przyzwyczajony po ciemnościach jaskini - bolą go oczy, więc się odwraca i ucieka od rzeczy, na które nie potrafi patrzeć; dopiero, gdy się przyzwyczai, będzie patrzył bezpośrednio w słońce, a nie na jego odbicie w wodzie. Poznawszy inny świat, człowiek zaczyna odczuwać litość nad swoimi współbraćmi z jaskini - wie, że świat, w którym żyją, jest światem narzuconych wytworów. Dlatego też powraca, aby opowiedzieć im o świecie Prawdy. Jest jednak wyśmiewany przez dawnych współbraci. Mówią, że „chodzi na górę, a potem wraca z zepsutymi oczami, i że nie warto nawet chodzić tam pod górę"s. Jaskiniowcy nie są wspólnotą otwartą na argumentację człowieka, który powrócił z innego świata, aby przynieść im światło. Wszelkie próby wyswobodzenia ich z kajdan kończą się agresją, a nawet atakiem na życie człowieka, który wyłamał się ze wspólnotowego myślenia.

Platon oferuje własną wykładnię metafory: jaskinię można

przyrównać do mieszkania w więzieniu, a światło ognia w nim do siły słońca. Wchodzenie pod górę i oglądanie tego, co jest tam wyżej, jeśli weźmiesz za wznoszenie się duszy do świata myśli, to nie zbłądzisz [...] [N]a szczycie świata myśli świeci idea Dobra i bardzo trudno ją dojrzeć, ale kto ją dojrzy, ten wymiarkuje, że ona jest dla wszystkiego przyczyną, co słuszne i piękne, że w świecie widzialnym pochodzi od niej światło i jego pan, a w świecie myśli ona panuje i rodzi prawdę i rozum, i że musi ją dojrzeć ten, który ma postępować rozumnie w życiu prywatnym lub w publicznym 6 .

Powyższy cytat z księgi VII przedstawia Platońską koncepcję państwa idealnego. Odwołując się do metafory jaskini, Platon wychodzi od problemu różnicy pomiędzy postrzeganiem zmysłowym, które cechuje mieszkańców jaskini, a poznaniem rozumowym. Następnie opisuje drogę poznania Dobra, które jest ojcem Prawdy, aby w końcu dojść do koncepcji państwa, które on uważa za idealne, czyli państwa zbudowanego na idei Dobra, Prawdy i Piękna. Według Platona postrzeganie zmysłowe jest postrzeganiem mylnym i zwodniczym ludzie opierający swoje poznanie na zmysłach doświadczają jedynie poznania pozornego, gdyż mylnie biorą „cienie wytworów” za prawdę. Ponadto poznanie zmysłowe wykształca głównie umiejętność myślenia obrazami, a więc kształtuje mniemania, którymi dysponują tzw. „szerokie koła”, opisując otaczającą je rzeczywistość ${ }^{7}$. Jest to najniższy stopień wiedzy. Na przeciwległym biegunie znajduje się poznanie rozumowe, czyli poznanie samej idei,

\footnotetext{
5 Tamże, s. 363.

6 Tamże, s. 363 i n.

7 Tamże, s. 384.
} 
osiągalne za pomocą pojęć - „ucieczki do słów”8. Światło w świecie widzialnym jest, zdaniem Platona, symboliczną gwarancją istnienia Prawdy w świecie myśli. „Wznoszenie się duszy do świata myśli” to pragnienie Prawdy, zrodzonej z idei Dobra. Prawda i rozum są niezbędne do powstania i istnienia państwa idealnego, gdyż tylko ci, którzy poznali Prawdę, powinni sprawować władzę w państwie. Ponieważ każdy człowiek ma duszę, jest on również zdolny do poznania Prawdy, dokonując „obrotu duszy” za pomocą rozumu ku Prawdzie. Człowiek, który patrzył bezpośrednio w światło, a więc poznał Prawdę, zostaje „uleczon[y] z nieświadomości”, gdyż „Zwrócił się do czegoś, co bardziej istnieje”, do czegoś „,bliższego bytu”, czyli do Prawdy9. Umiejętność ,nawracania się” ma każdy człowiek in potentia, gdyż ma on duszę: Platon twierdzi, że ,nie chodzi o to, żeby człowiekowi wszczepiać wzrok, on go ma, tylko się w złą stronę obrócił i nie patrzy tam, gdzie trzeba" ${ }^{10}$. „,[O]dwrócenie się od cieni do wizerunków samych i do światła, oto jest wyjście w górę z podziemia na słońce, [...] który olśniewa tak, że patrzeć trudno, ale odbicia w wodach tego, co boskie, i cienie bytów rzeczywistych tam widzieć można" ${ }^{11}$. Tak więc człowiek patrzący w światło, ogląda nie obraz, lecz Prawdę, poznaje byt wieczny, a nie zjawiska, które przemijają, przebywa drogę od poznania zmysłowego ku poznaniu rozumowemu. Poznawszy Prawdę, potrafi ,rozpoznać każde widmo"12. Przywilejem tym Platon obdarzył anaxa - człowieka, któremu udało się wydostać z jaskini i powrócić, aby otworzyć swoim dawnym towarzyszom oczy na Prawdę.

Platońska jaskinia to wspólnota ludzi, w której, jak w każdej wspólnocie, dochodzi do rywalizacji mimetycznej: ,,szerokie koła” prześcigają się w mniemaniach na temat wytworów. Rywalizują o to, kto najtrafniej odgadnie, co widzi, najdokładniej zapamięta i najlepiej przepowie przyszłe widma. Pojawienie się anaxa scala wspólnotę - jej członkowie jednomyślnie opowiadają się przeciwko niemu: ,gdyby tylko mogli chwycić coś w garść i zabić go, na pewno by go zabili"'13. Owa jednomyślność w postępowaniu jest reakcją na odmienność innego, który zburzył im spokój, zniszczył dotychczasowe poczucie bezpieczeństwa i równości wszystkich obywateli. Ponieważ jest inny, jako że poznał Prawdę, może chcieć postrzegać siebie jako lepszego od pozostałych, mniemają jaskiniowcy. Poniekąd zazdroszczą mu, że widział inny świat i zasmakował wolności poza wspólnotą. Gdyby go rzeczywiście zabili, zrobiliby to z nieuświadomionej zawiści, a on stałyby się niewinną ofiarą. Według

\footnotetext{
${ }^{8}$ Platon, Fedon, tłum. W. Witwicki, Warszawa 1958, s. 115.

9 Platon, Platona Państwo z dodatkiem siedmiu ksiag ,Praw”, dz. cyt., s. 360 i n.

10 Tamże, s. 366.

11 Tamże, s. 391.

12 Tamże, s. 369.

13 Tamże, s. 363.
} 
Emmanuela Lévinasa „,[z]abójstwo jest pokusą zdobycia władzy nad czymś, co wymyka się wszelkiej władzy. [...] Mogę chcieć zabić tylko byt absolutnie niezależny, który nieskończenie przerasta moją władzę, który zatem nie przeciwstawia się jej, lecz paraliżuje samą możność władzy"14. Członkowie wspólnoty podejrzewają, że anax chce nimi zawładnąć. I nie bez racji, gdyż jego zadaniem jest zmuszanie mieszkańców jaskini do obierania drogi wzwyż, a narzędziem władzy staje się dialektyka stojąca na czele nauk, sztuka prowadzenia rozumnej rozmowy, której celem jest dążenie do poznania Prawdy. W państwie idealnym jest ona również narzuconym przez prawo sposobem myślenia: „Zatem przykażesz im prawem, żeby się najwięcej garnęli do tej dyscypliny, dzięki której potrafią najmądrzej zadawać pytania i dawać odpowiedzi?" 15 . Jest to również sposób nauczania, za pomocą którego anax staje się pośrednikiem pomiędzy dawnymi współtowarzyszami z jaskini a światem Prawdy. Celem jego nauczania opartego na dialektyce jest wzbudzenie pragnienia Prawdy wśród jaskiniowców. Nie jest to jednak ich własne pragnienie, lecz pragnienie zapożyczone, i to zapożyczone podwójnie: przez osobę pośrednika i przez ustanowione prawa, które nakazują pragnąć Prawdy. Celem anaxa jest jednak imitatio, czyli naśladowanie wzorca ${ }^{16}$, którym sam siebie ustanowił - każdy obywatel powinien pragnąć Prawdy dla wspólnego dobra wszystkich obywateli. Aby uniknąć konfliktu wynikającego z mimetycznej natury pragnienia, Platon oddaje władzę w ręce tych, którzy się do niej nie garną, gdyż takie rządy będą najlepsze i „najbardziej wolne od wewnętrznych niepokojów"17 - ,[...] do rządów nie powinni się brać ludzie, którzy się w rządzeniu kochają. Bo między zakochanymi rywalami muszą się zacząć walki"18.

Pragnienie mimetyczne rodzi konflikt, u którego podłoża leży nienawiść do rywala. Platon odróżnia pragnienie Prawdy od pragnienia władzy; mimo że pragnienie Prawdy jest zapośredniczone, oparte jest ono na naśladownictwie, a więc jest świadomym aktem i nie prowadzi do otwartego konfliktu. Dlatego też Platoński anax nie zostaje zamordowany przez współbraci. Początkowo nie mogli chwycić niczego i go zabić, gdyż byli skuci kajdanami, teraz żyją w państwie prawa. Ustanowione prawo szczegółowo i rygorystycznie zarządza nową wspólnotą: „[...] prawu nie na tym zależy, aby jakiś jeden rodzaj ludzi był osobliwie szczęśliwy; harmonizując obywateli namową i przymusem

${ }^{14}$ E. Lévinas, Całość i nieskończoność. Esej o zewnętrzności, thum. M. Kowalska, Warszawa 1998, s. 233.

15 Platon, Platona Państwo z dodatkiem siedmiu ksiag „, Praw”, dz. cyt., s. 395.

${ }^{16}$ Girard odróżnia naśladowanie od mimetyzmu: „Z mimetyzmem łączymy mniejszy stopień świadomości, z naśladownictwem - większy” - R. Girard, Początki kultury, dz. cyt., s. 66.

${ }_{17}$ Platon, Platona Państwo z dodatkiem siedmiu ksiag „Praw”, dz. cyt., s. 369.

18 Tamże, s. 370. 
skłania ich do tego, żeby się z sobą dzielili pożytkiem, jaki każdy potrafi przynieść dla wspólnego dobra" 19 . Państwo idealne opiera się na prawach, a nie na ekspresji „woln[ej] myśli” obywateli, którą Platon utożsamia z mniemaniem. Łamanie prawa jest konsekwencją obcowania $\mathrm{z}$ „myślami niezależnymi”" Z obawy przed chaosem i z troski o homogeniczność państwa jednym ze środków ostrożności będzie zakaz kosztowania „wolnej myśli” w młodym wieku: „I tak będą [prawdziwi filozofowie - przyp. A.G.] zawsze wychowywali drugie pokolenie ludzi takich samych, aby ich zostawić na straży około państwa" 21 . Państwo będzie im składało ofiary i stawiało pomniki „tak jak bogom"22. Owi „prawdziwi filozofowie” zajmą się również wychowaniem dzieci w odosobnieniu od rodziców, aby ci nie wywierali swoimi obyczajami zgubnego wpływu na przyszłe pokolenia. Taki model państwa, będący jednak zalążkiem państwa totalitarnego, będzie zapewniać, zdaniem Platona, szczęście wszystkim obywatelom. Platon ukazuje tłumienie pragnienia mimetycznego i to właśnie owo thumienie staje się fundamentem dla powstania idealnego państwa, opartego na szeregu praw i zakazów. Niestłumione pragnienie mimetyczne doprowadziłoby do wybuchu przemocy i śmierci niewinnej ofiary, która ukazała Prawdę. Dlatego też pragnienie Prawdy nie powinno odwoływać się do mechanizmu mimetycznego, lecz do świadomego naśladownictwa ideału, gdyż to właśnie poznanie Prawdy, jak mniema Platon, umożliwia powstanie idealnego państwa, stworzonego dla dobra wszystkich obywateli.

\section{Stary Testament}

Podobny do Platońskiego mechanizm thumienia pragnienia mimetycznego ukazuje Stary Testament. Mojżesz to w pewnym sensie prekursor Platońskiego anaxa i nowotestamentowego Chrystusa. Cudownie ocalony z rzezi niemowląt, już jako dorosły mężczyzna, z zawodu pasterz, zostaje wybrany przez Boga i powołany na przywódcę narodu, który ma wyprowadzić z niewoli egipskiej. Gdy przebywa na górze Horeb, pasąc owce swojego teścia, ukazuje mu się anioł Pański w płonącym krzewie, który jednak nie ulega zniszczeniu od ognia. Zaciekawiony tym niezwykłym zjawiskiem Mojżesz podchodzi do krzewu, z którego środka przemawia do niego Bóg. Mojżesz zasłania jednak twarz, gdyż boi się spojrzeć na Boga. W ten sposób Biblia, podobnie jak Platon, ukazuje niemożność bezpośredniego poznania Bytu absolutnego, którym jest Bóg: „JESTEM, KTÓRY JESTEM [...] JESTEM, Bóg ojców waszych, Bóg Abrahama, Bóg

\footnotetext{
19 Tamże, s. 368.

20 Tamże, s. 403.

21 Tamże, s. 406.

22 Tamże, s. 406.
} 
Izaaka i Bóg Jakuba posłał mnie do was. To jest imię moje na wieki i to jest moje zawołanie na najdalsze pokolenia" (Wj 3,14-15)23. Bóg objawia Mojżeszowi swoje plany wobec niego i Izraela, czyniąc Mojżesza pośrednikiem pomiędzy Nim a narodem wybranym. Aby lud Izraela uwierzył Mojżeszowi w objawienie Boga, zostaje on wyposażony w umiejętność czynienia znaków, dostaje do pomocy elokwentnego Aarona, aby umiał przemawiać, i staje się początkowo tylko dla niego, a później dla całej wędrującej wspólnoty, ,jakby Bogiem” (Wj $4,16)$. Owo przeniesienie metonimiczne ma decydujące znaczenie dla starotestamentowej koncepcji poznania zmysłowego i rozumowego.

W przeciwieństwie do Platona, który, ukazując ewolucję wiedzy, umieszcza poznanie zmysłowe na szczeblu drugim od końca, nieco je degradując w ten sposób, Biblia traktuje poznanie zmysłowe jako etap, który poprzez wiarę umożliwia poznanie rozumowe. To za pomocą zmysłu wzroku (doświadczenie cudów) oraz zmysłu słuchu (słuchanie nauczania Bożego) Izraelici poznają pośrednio Byt absolutny utożsamiany z Prawdą. Jednak to dopiero poznanie rozumowe jest poznaniem prawdziwym, transcendencją poznania zmysłowego, które jest tylko ,jakby” poznaniem, tak jak Mojżesz nie jest prawdziwym Bogiem, ale ,jakby Bogiem”, za którego pośrednictwem można doświadczyć Boga prawdziwego. Tak więc poznanie zmysłowe, które umożliwia pośrednie poznanie Bytu absolutnego, jest metonimią poznania rozumowego, które jest możliwe za pośrednictwem języka i jego figur. Również Platon postuluje, że poznanie Bytu absolutnego jest możliwe jedynie na drodze poznania rozumowego, wyłącznie za pomocą słów i pojęć, gdyż świata idei nie można oglądać bezpośrednio, a więc i Prawda nie jest bezpośrednio dostępna. W świecie Biblii bezpośrednie oglądanie Bytu grozi nawet śmiercią. Bóg objawia się Izraelitom pod postacią gęstego obłoku na górze Synaj, lecz zabrania im, wyjąwszy Mojżesza, wstępować na górę: „Zstąp na dół i upomnij lud surowo, aby się nie zbliżali do Pana, chcąc go zobaczyć, gdyż wielu z nich przepłaciłoby to życiem" (Wj 19,21).

Symbolicznym miejscem poznania Boga, a więc i Prawdy, jest - podobnie jak u Platona - góra. Aby poznać Prawdę, należy się wspiąć na górę, a sama wspinaczka jest tożsama z Jej pragnieniem. Mojżesz, podobnie jak Platoński anax, jest jedynym, któremu dane jest bezpośrednie oglądanie Boga, a więc i poznanie Prawdy, która zostaje mu przekazana w formie praw na górze Synaj. To on uczestniczy w spisaniu owych praw i pośredniczy w przekazaniu ich Izraelowi. Konstytutywne dla wspólnoty i koncepcji pragnienia Prawdy są zakazy idolatrii, pożądania i zabijania. Już w pierwszym przykazaniu Dekalogu Bóg zapewnia sobie wyłączność, ustanawiając zakaz idolatrii:

${ }^{23}$ Wszystkie cytaty z Biblii pochodzą z: Biblia Tysiaclecia, red. K. Dynarski, Poznań-Warszawa 1989. 
Nie będziesz miał cudzych bogów obok Mnie! Nie będziesz czynił żadnej rzeźby ani żadnego obrazu tego, co jest na niebie wysoko, ani tego, co jest na ziemi nisko, ani tego, co jest w wodach pod ziemią! Nie będziesz oddawał im pokłonu i nie będziesz im służył, ponieważ Ja Pan, twój Bóg, jestem Bogiem zazdrosnym, który każe występek ojców na synach do trzeciego i czwartego pokolenia względem tych, którzy Mnie nienawidzą. Okazuję zaś łaskę aż do tysięcznego pokolenia tym, którzy Mnie miłują i przestrzegają moich przykazań (Wj 20,3-6).

Dla Boga istnieją pewne granice owej ,przystawalności” poznania zmysłowego i poznania rozumowego, których przekroczenie jest karalne na mocy Prawa Przymierza ustanowionego dla Izraela. Zakaz dotyczy tworzenia i wielbienia obrazów na podobieństwo Boga, a więc - jakby chciał Platon - obrazów będących cieniem Prawdy, a nie samą Prawdą, kreujących mniemania, a nieprowadzących do rozumowego poznania Prawdy. Gdy Mojżesz przebywa przez czterdzieści dni i czterdzieści nocy z Bogiem na górze Horeb, lud prosi Aarona, aby ten stworzył mu obraz boga, którego mógłby wielbić na podobieństwo ludów pogańskich: „Uczyń nam boga, który by szedł przed nami, bo nie wiemy, co się stało z Mojżeszem, tym mężem, który wyprowadził nas z ziemi egipskiej" (Wj 32,1). Aaron każe przetopić złoto i tworzy wizerunek cielca, któremu Izraelici oddają pokłon, co wywołuje gniew Boży i chęć zagłady narodu:

Zstąp na dół, bo sprzeniewierzył się lud twój, który wyprowadziłeś z ziemi egipskiej. Bardzo szybko odwrócili się od drogi, którą im nakazałem, i utworzyli sobie posąg cielca ulanego z metalu i oddali mu pokłon, i złożyli mu ofiary, mówiąc: Izraelu, oto twój bóg, który cię wyprowadzit z ziemi egipskiej. Zostaw mnie przeto w spokoju, aby rozpalił się mój gniew na nich. Chcę ich wyniszczyć, a ciebie uczynić wielkim ludem (Wj 32,7-8.10).

Izraelici wykraczają podwójnie przeciw prawu Bożemu: nie tylko tworzą zakazany wizerunek, ale także, naśladując w swoich praktykach pogan, wielbią coś, co jest jedynie cieniem Prawdy. Potrzeba opartego na mimetyzmie poznania zmysłowego jest jednak silnie zakorzeniona w ludzie. Dlatego Bóg zezwala na budowę pełnej przepychu świątyni, miejsca kultu Bożego, wybierając do tego zadania tych, którzy zdołali wyjść poza poznanie zmysłowe: ,[...] wszyscy biegli mężczyźni, którym Pan dał mądrość, rozum do poznania, niech wykonają wszelkie prace przy budowie świętego przybytku według wszelkich nakazów Pana" (Wj 36,1). Poznanie i czczenie Boga utożsamianego z Prawdą możliwe jest na drodze przekroczenia poznania zmysłowego ku poznaniu rozumowemu, gdyż samo pragnienie mimetyczne zapośredniczone za pomocą zmysłów jedynie oddala od Prawdy. Mimetyzm rodzi zazdrość, od której nawet Bóg nie jest wolny: „Nie będziesz oddawał pokłonu 
bogu obcemu, bo Pan ma na imię Zazdrosny: jest Bogiem zazdrosnym” (Wj 34,14). Bóg jednak wie, że powyższy nakaz zostanie ponownie złamany, a On zasłoni swoje oblicze i opuści lud wybrany (Pwt 31,17). Oglądanie oblicza Pana dane jest tylko wybranym: „Ja ukażę ci mój majestat i ogłoszę przed tobą imię Pana, gdyż Ja wyświadczam łaskę, komu chcę, i miłosierdzie, komu Mi się podoba” (Wj 33,19). Łaski oglądania Boga „twarzą w twarz”, a więc prawdziwego poznania oblicza Pana, nie za pośrednictwem wytworzonego wizerunku, lecz poprzez język, doznaje jedynie Mojżesz: „Twarzą w twarz mówię do niego - w sposób jawny, a nie przez wyrazy ukryte. On też postać Pana ogląda" (Lb 12,8). Odsłaniając tajemnicę swojego oblicza przed Mojżeszem, Bóg wchodzi z nim w dialog, nawiązuje rozmowę, która otwiera mu drogę do poznania Prawdy: „Prawdy mogę szukać dlatego, że nawiązałam już stosunek z twarzą" ${ }^{24}$. To relacja „twarzą w twarz”, twierdzi dalej Lévinas, utożsamiając język z rozumem, stanowi podstawę języka, który umożliwia poznanie rozumowe ${ }^{25}$.

Mojżesz jest wybranym spośród wybranych, który doznał łaski Bożej. Jej odzwierciedleniem jest światłość bijąca od proroka:

Gdy Mojżesz zstępował z Góry Synaj z dwiema tablicami Świadectwa w ręku, nie wiedział, że skóra na jego twarzy promieniała na skutek rozmowy z Panem. Gdy Aaron i Izraelici zobaczyli Mojżesza z daleka i ujrzeli, że skóra na jego twarzy promienieje, bali się zbliżyć do niego. [...] Gdy Mojżesz zakończył z nimi rozmowę, nałożył zasłonę na twarz. Ilekroć Mojżesz wchodził przed oblicze Pana na rozmowę z Nim, zdejmował zasłonę aż do wyjścia. Gdy zaś wyszedł, opowiadał Izraelitom to, co mu Pan rozkazał. I wtedy to Izraelici mogli widzieć twarz Mojżesza, że promienieje skóra na twarzy Mojżesza. A Mojżesz znów nakładał zasłonę na twarz, póki nie szedł na rozmowę z Nim (Wj 34,29-30.33-35).

Biblijna symbolika światła nie odbiega daleko od symboliki Platona. Zarówno grecki filozof, jak i Pismo Święte, utożsamiają światło z poznaniem Prawdy. Podobnie jak Platoński anax, Mojżesz przemierza drogę od ciemności do światłości i z powrotem. Przynosząc Dekalog ze spotkania z Bogiem, staje się on nosicielem Prawdy, zawartej w formie nakazów i zakazów. Jest on nauczycielem-pośrednikiem pomiędzy Bogiem a Jego ludem, lecz nauczanie to dla niego żmudna praca, gdyż Izraelici, podobnie jak jaskiniowcy, są sceptycznie nastawieni do przekazywanych im słów, a wzbudzenie pragnienia Prawdy wydaje się wręcz niemożliwe wobec nieustających buntów wspólnoty. Za niedostatki, zwłaszcza brak wody i pożywienia, oraz wszelkiego rodzaju nieszczęścia i przeciwności na drodze do Ziemi Obiecanej lud wini

\footnotetext{
${ }^{24}$ E. Lévinas, Całość i nieskończoność. Esej o zewnętrzności, dz. cyt., s. 238.

${ }^{25}$ Tamże, s. 245.
} 
Mojżesza, który staje się niejako kozłem ofiarnym: „Czy po to wyprowadziłeś nas z Egiptu, aby nas, nasze dzieci i nasze bydło wydać na śmierć z pragnienia?” (Wj 17,3). Podobnie jak wspólnota mieszkająca w Platońskiej jaskini, Izraelici wspominają czasy dostatku w niewoli egipskiej: żądają mięsa, gardząc zesłaną przez Boga manną. W odpowiedzi Pan zsyła przepiórki, których nadmiar powoduje śmierć tych, którzy nie mogą oprzeć się pożądaniu: „Mięso jeszcze było między ich zębami, jeszcze nie przeżute, gdy już zapalił się gniew Pana przeciw ludowi i uderzył go Pan wielką plagą. Dlatego też nazwano to miejsce Kibrot-Hattaawa [Groby Pożądania], bo tam pochowano ludzi, których opanowało pożądanie" (Lb 11,33-34). Biblijne pożądanie, w przeciwieństwie do pragnienia, jest uzewnętrznieniem lęku wynikającego z braku, a przeradza się w agresję skierowaną na niewinną ofiarę. Gdy Izraelici napotykają coraz więcej przeciwności na swojej drodze, otwarcie występują przeciwko Mojżeszowi i Aaronowi. W akcie zemsty chcą ich ukamienować i powrócić do Egiptu. Jednocześnie oskarżają ich o chęć zawładnięcia wspólnotą:

Dość tego, gdyż cała społeczność, wszyscy są świętymi i pośród nich jest Pan; dlaczego więc wynosicie się ponad zgromadzenie Pana? [...] Czyż nie dość tego, żeś nas wyprowadził z kraju opływającego w mleko i miód, by nas wygubić na pustyni, ale jeszcze chciałbyś sobie przywłaszczyć władzę nad nami? Przecież to nie jest kraj opływający w mleko i miód, gdzie nas wyprowadziłeś, ani nie dałeś nam jako dziedzictwa pól i winnic. Sądzisz, że możesz tym ludziom odebrać oczy? (Lb 16,3.13-14).

Biblia odróżnia pragnienie od pożądania, zakazując ostatniego. Pożądanie może być rozumiane jako czysta żądza posiadania czegoś w nadmiarze, czyli zwykła chciwość, lub też jako pożądanie cudzej własności i jako takie jest zakazane na mocy dziesiątego przykazania, lecz pożądaniem jest również pożądanie innego pożądania lub pragnienia. Izraelici zazdroszczą Mojżeszowi obcowania z Bogiem „twarzą w twarz”, gdyż tylko on został wybrany, aby dostąpić łaski poznania Prawdy, która dała mu władzę nad innymi. Dlatego też pożądają oni tego samego dla siebie. Ich pożądanie nie jest pragnieniem Prawdy dla niej samej, ale dla korzyści, jakie poznanie Prawdy przynosi, a więc jest to pożądanie władzy, u którego podstaw leży zwykła zazdrość rodząca przemoc. W pracy Mojżesz i monoteizm Zygmunt Freud, nawiązując do swoich wcześniejszym rozważań, postuluje tezę, że Mojżesz został zamordowany na pustyni przez Izraelitów, którzy zbuntowali się przeciw surowym nakazom religijnym i jego tyrańskiej władzy. Wielokrotne bunty ludu były krwawo thumione zgodnie z nakazem Jahwe. Jeden z takich buntów musiał zakończyć się śmiercią Mojżesza: „A kiedy zabili tego wielkiego człowieka, powtórzyli jedynie nieprawość, która w czasach pierwotnych była prawem skierowanym 
przeciw boskiemu królowi i która, jak wiemy, wywodzi się z jeszcze starszego prawzoru" 26 . Wkrótce potem Izraelici pożałowali swojego czynu, który stopniowo został wyparty z ich świadomości historycznej. W zamian, wnioskuje Freud, zaczęli czcić Mojżesza jako wodza, który ich wyprowadził z Egiptu. Jednak wbrew jego spekulacjom, Mojżesz, podobnie jak Platoński anax, nie zostaje ukamienowany przez Izraelitów - zakazuje tego prawo, a dokładnie przykazanie Dekalogu: „Nie będziesz zabijał” (Wj 20,13). Zdaniem Léviansa, przykazanie to uobecnia się również w epifanii twarzy, która jest jednocześnie pokusą zabójstwa i jego zakazem ${ }^{27}$. Tym samym to stłumiona agresja leży u podstaw wspólnoty opartej na starotestamentowym zakazie zabójstwa.

\section{Nowy Testament}

Platoński anax i Mojżesz są tymi, którzy świadczą o Prawdzie, gdyż obcowali z Nią „twarzą w twarz”. Ich odmienność skutkuje zazdrością innych, a w konsekwencji rodzi pożądanie ich pragnienia, które wywołuje przemoc. Nigdy jednak nie dochodzi do zabójstwa niewinnej ofiary. Nowotestamentowe pragnienie Prawdy oparte jest na nieco innym mechanizmie przy zachowaniu tej samej symboliki. Pierwszy rozdział Ewangelii według św. Jana nosi znaczący tytuł „Działalność Jezusa Chrystusa jako Słowa, Światłości i Życia”. W tym miejscu grecki Logos odwołuje się nie tylko do epifanii Boga Ojca pod postacią Jezusa Chrystusa, ale także do rozumowego poznania Prawdy. Ocalony z rzezi niewiniątek Jezus, podobnie jak Mojżesz, staje się nauczycielem i głosicielem Prawdy: za pośrednictwem słowa daje świadectwo Słowu, czyli Prawdzie, utożsamianej z Bogiem i będącej siłą sprawczą wszelkiego działania: „Na początku było Słowo, a Słowo było u Boga, i Bogiem było Słowo. Ono było na początku u Boga. Wszystko przez Nie się stało, a bez Niego nic się nie stało, co się stało. W Nim było życie, a życie było światłością ludzi, a światłość w ciemności świeci i ciemność jej nie ogarnęla" (J 1,1-5). Również w Nowym Testamencie mamy do czynienia z symboliką światła znaną nam z Platońskiej jaskini i Starego Testamentu, gdzie światłość była symbolem drogi, która wiodła ku Prawdzie, oraz zwiastunem nadchodzącego Boga, niejako wizualnym środkiem komunikacji pomiędzy Nim a człowiekiem. Jednak już na samym początku Ewangelii Jan przepowiada odwrócenie się narodu od prawdziwej światłości $(J$ 1,9) i odrzucenie słowa głoszonego przez Jezusa: ,[...] świat Go nie poznał. Przyszło do swojej własności, a swoi

${ }^{26}$ Z. Freud, Mojżesz i monoteizm, w Człowiek, religia, kultura, tłum. J. Prokopiuk, Warszawa 1967, s. 208.

${ }^{27}$ Por. E. Lévinas, O Bogu, który nawiedza myśl, tłum. M. Kowalska, Kraków 2008, s. 268. 
Go nie przyjęli" (J 1,10-11). Odrzucenie Słowa jest tożsame z odrzuceniem Jezusa, a tym samym i Prawdy. Jezus, nauczając, usiłuje wpłynąć na zmianę moralnej postawy człowieka i wzbudzić w nim pragnienie Prawdy. Posługując się podobną do Platońskiej symboliką światła i ciemności, opisuje On człowieka prawego i człowieka grzesznego:

[...] światło przyszło na świat, lecz ludzie bardziej umiłowali ciemność aniżeli światło: bo złe były ich uczynki. Każdy bowiem, kto się dopuszcza nieprawości, nienawidzi światła i nie zbliża się do światła, aby nie potępiono jego uczynków. Kto spełnia wymagania prawdy, zbliża się do światła, aby się okazało, że jego uczynki są dokonane w Bogu (J 3,19-21).

Uderzające jest również podobieństwo, z jakim Platon i Jezus opisują stopnie poznania Prawdy. Platon opisuje cztery rodzaje wiedzy, począwszy od doksy - poznania opartego na mniemaniach, poprzez pistis odnoszącą się do poznania obrazowego wyrażanego za pomocą symboli i dianoię zawierającą wiedzę na temat rzeczy, a skończywszy na epistemie, czyli najwyższym stopniu poznania, gdyż jest to rozumowe poznanie samej idei ${ }^{28}$. W przypowieści o siewcy, który sieje słowo, Jezus rozróżnia cztery drogi dążenia do Prawdy: najniżej ocenia On poznanie zmysłowe ex auditu, które prowadzi do wytwarzania mniemań, a wyklucza poznanie rozumowe: „Do każdego, kto słucha słowa o królestwie, a nie rozumie go, przychodzi Zły i porywa to, co zasiane jest w jego sercu. Takiego człowieka oznacza ziarno posiane na drodze" (Mt 13,19). Drugi i trzeci rodzaj poznania dotyczą osób, które zasłyszawszy słowo Boże, przyjmują je, a więc nabywają jakiś rodzaj wiedzy, lecz przeszkody świata zewnętrznego, zwłaszcza żądze, powodują, że nie są w stanie podążać dalej w kierunku pełnego poznania Prawdy:

Posiane na miejsca skaliste oznacza tego, kto słucha słowa i natychmiast z radością je przyjmuje; ale nie ma w sobie korzenia, lecz jest niestały. Gdy przyjdzie ucisk lub prześladowanie z powodu słowa, zaraz się załamuje. Posiane między ciernie oznacza tego, kto słucha słowa, lecz troski doczesne i ułuda bogactwa zagłuszają słowo, tak że zostaje bezowocne (Mt 13,20-22).

Poznanie to oscyluje pomiędzy Platońską pistis i dianoia. Świadczy ono o chęci zdobycia wiedzy, lecz nie jest doskonałe, gdyż człowiek daje się odciągnąc od słowa przez obrazy zaczerpnięte ze świata zewnętrznego. Dopiero ostatni rodzaj poznania jest poznaniem prawdziwym, gdyż dotyczy poznania i zrozumienia słowa oraz przekucia go w czyn: „Posiane w końcu na ziemię żyzną oznacza tego, kto słucha słowa i rozumie je. On też wydaje

${ }^{28}$ Platon, Platona Państwo z dodatkiem siedmiu ksiag „Praw”, dz. cyt., s. 392 i nn. 
plon: jeden stokrotny, drugi sześćdziesięciokrotny, inny trzydziestokrotny" (Mt 13,23). Tak więc poznanie tajemnicy królestwa niebieskiego jest możliwe dzięki rozumowemu podążaniu ku światłości symbolizowanej przez Jezusa. Podobnie jak od Mojżesza obcującego z Bogiem, tak i od Jezusa bije światłość, gdyż przychodzi On od Ojca. Podobnie jak Platoński anax, tak i Jezus przychodzi z wysokości, aby głosić Słowo: „Wy jesteście z niskości, a Ja jestem z wysoka. Wy jesteście z tego świata, Ja nie jestem z tego świata. [...] [J]eżeli nie uwierzycie, że JA JESTEM, pomrzecie w grzechach swoich" (J 8,23-24). Nawiązując do słów Ojca, który objawił się Mojżeszowi w Księdze Wyjścia, Jezus wyjawia swoje boskie pochodzenie. Wiara w tożsamość Jezusa Chrystusa i Ojca jest fundamentem chrześcijaństwa i oparta jest na zrozumieniu słowa, a w konsekwencji na rozumowym pojęciu przeistoczenia Słowa w ciało: „A Słowo stało się ciałem i zamieszkało wśród nas. I oglądaliśmy Jego chwałę, chwałę, jaką Jednorodzony otrzymuje od Ojca, pełen łaski i prawdy" (J 1,14). Aby uczniowie poznali Prawdę o Jego boskim pochodzeniu, Jezus zabiera ich ze sobą na górę, gdzie ukazuje się im Mojżesz, Eliasz, a w obłoku świetlistym sam Bóg: ,[...] twarz Jego zajaśniała jak słońce, odzienie zaś stało się białe jak światło [...] oto obłok świetlany osłonił ich, a z obłoku odezwał się głos: To jest mój Syn umiłowany, w którym mam upodobanie, Jego stuchajcie!" (Mt 17,2.5).

Warunkiem poznania Prawdy jest nie tylko zrozumienie słowa, ale przede wszystkim przekucie go w czyn poprzez naśladowanie wzorca - imitatio Chri$s t i$ - którym Jezus ustanawia siebie: „Ja jestem światłością świata. Kto idzie za Mną, nie będzie chodził w ciemności, lecz będzie miał światło. [...] Jeśli kto chce pójść za Mną, niech się zaprze samego siebie, niech weźmie krzyż swój i niech Mnie naśladuje" (J 8,12; Mt 16,24). Jezus obiecuje tym, którzy będą Go naśladować, obcowanie ze światłością, a więc życie wieczne, do osiągnięcia którego poznanie zmysłowe jest niewystarczające. Nowy Testament nie degraduje jednak poznania zmysłowego, tak jak czyni to Platon - otwieranie oczu przez Jezusa jest rozumiane metaforycznie jako nawracanie, otrzymywanie wiary potrzebnej do rozumowego poznania świata niewidzialnego: „Jezus [...] dotknął ich oczu, a natychmiast przejrzeli i poszli za Nim. [...] Jezus zaś tak wołał: Ten, kto we Mnie wierzy, wierzy nie we Mnie, lecz w Tego, który Mnie postał. A kto Mnie widzi, widzi Tego, który Mnie posłal' (Mt 20,34; $\mathrm{J} 12,44-45)$. W ten sposób wzbudza w ludzie pragnienie Prawdy, zakorzenione w świadomym naśladownictwie. Ustanawia również nowe przykazanie, które jest imperatywem do osiągnięcia życia wiecznego, a oparte jest na mechanizmie świadomego naśladowania Jezusa: „Przykazanie nowe daję wam, abyście się wzajemnie miłowali, tak jak Ja was umiłowałem" (J 13,34) oraz naśladowania miłości własnej w obcowaniu z bliźnim: „Będziesz miłował Pana, Boga swego, całym swoim sercem, cała swoja dusza, cała swoja moca i całym 
swoim umystem; a swego bliźniego jak siebie samego" (Łk 10,27). W swoim poświęceniu dla ludzkości Jezus idzie dalej - oddaje własne życie za innych, aby oni mogli poznać Prawdę: „Dlatego miłuje mnie Ojciec, bo Ja życie moje oddaję, aby je [potem] znów odzyskać. Nikt Mi go nie zabiera, lecz Ja od siebie go oddaję. Mam moc je oddać i mam moc je znów odzyskać. [...] A za nich Ja poświęcam w ofierze samego siebie, aby i oni byli uświęceni w prawdzie" (J 10,17-18; J 17,19). Jezus podkreśla, że Jego poświęcenie jest świadome i dobrowolne. W imię miłości bliźniego tego samego oczekuje od swoich naśladowców: „Nikt nie ma większej miłości od tej, gdy ktoś życie swoje oddaje za przyjaciół swoich" (J 15,13).

Nowy Testament odróżnia świadome naśladownictwo zapoczątkowane przez Jezusa od mimetyzmu. Naśladowanie Chrystusa umożliwia poznanie Prawdy, mimetyzm natomiast rodzi zazdrość o Prawdę, nie dla niej samej, ale dla innych korzyści. Podkreślając swoją wyjątkowość i inność, czyli - idąc za Girardem - uwidaczniając swoje „stygmaty ofiarnicze”29, Jezus ściąga sam na siebie zawiść wspólnoty, która nieuchronnie prowadzi do wybuchu przemocy. Żydzi uporczywie szukają podstaw prawnych, aby Go ukarać i pozbawić życia. Usiłują Go ukamienować za treść Jego nauki odstępującej od surowych praw kanonicznych, uzdrawianie w szabat, czynienie cudów, a przede wszystkim za nazywanie się Synem Bożym, co uważają za bluźnierstwo. Jezus twierdzi, że jest nienawidzony, gdyż ukazuje światu jego złe uczynki (J 7,7); nieugięcie uważa swoje sądy za prawdziwe: „sąd mój jest prawdziwy, ponieważ Ja nie jestem sam, lecz Ja i Ten, który Mnie posłał. [...] Teraz usiłujecie Mnie zabić, człowieka, który wam powiedział prawdę usłyszaną od Boga" (J 8, 16, 40). Jezus ostatecznie pada ofiarą mimetyzmu. Girard twierdzi, że „Chrystus jest nienawidzony bez powodu, kiedy wszyscy zaczynają naśladować thum Jego wrogów. Piłat naśladuje tłum swoim lękiem i również Piotr naśladuje tłum" ${ }^{30}$. Niewątpliwie prawdą jest, że Jezus jest kozłem ofiarnym i ginie bez winy, którą można by udowodnić paragrafami prawa, lecz na pewno nie jest nienawidzony bez powodu, choć On sam tak twierdzi: „Nienawidzili mnie bez powodu" (J 15,25). Prawda, którą głosi Jezus, podobnie jak Mojżesz czy Platoński anax, to Prawda, której zaakceptowanie musi nieuchronnie prowadzić do podziału wspólnoty, co budzi lęk konserwatywnych jej członków, gdyż narusza poczucie integralności narodu. Jednocześnie fakt, że Jezus zdołał zjednoczyć wokół siebie część Żydów, rodzi zawiść, gdyż oznacza to, że pragnie przejąć władzę. Oparte na świadomym mechanizmie naśladowczym pragnienie Prawdy, które Jezus usiłuje rozbudzić swoim nauczaniem, przeradza się w żądzę władzy, która dzieli wspólnotę i rodzi przemoc. U jej podstaw leży

\footnotetext{
29 R. Girard, Kozioł ofiarny, tłum. M. Goszczyńska, Łódź 1991, s. 33.

30 Tenże, Początki kultury, dz. cyt., s. 120.
} 
uzasadniony lęk o homogeniczność żydowskiej wspólnoty. To właśnie dlatego Żydzi są przekonani o winie swojej ofiary, choć nie potrafią tego udowodnić, kierując się raczej poznaniem intuicyjnym niż rozumowym. Jezus podkreśla, że nienawiść jest wynikiem niepoznania Prawdy, a mechanizm mimetyczny, który jednoczy wspólnotę $\mathrm{w}$ nienawiści do ofiary, jest nieświadomym działaniem. Dlatego też prosi Ojca o przebaczenie oprawcom, gdyż „nie wiedzą, co czynią" (Łk 23,34). Morderstwo Jezusa przywraca pokój we wspólnocie, choć prześladowani za Prawdę będą Jego uczniowie: „Wtedy wydadzą was na udrękę i będą was zabijać, i będziecie w nienawiści u wszystkich narodów, z powodu mego imienia. [...] Będą tak czynić, bo nie poznali ani Ojca, ani Mnie" (Mt 24,9; J 16,3). Jezus umiera dobrowolnie za dobro wspólnoty, gdyż wie, że Jego ofiara ją ponownie zjednoczy i umocni w jej członkach pragnienie Prawdy. Staje się w ten sposób dobroczynnym sacrum, barankiem Bożym, który z miłości do człowieka podczas ostatniej wieczerzy zawiera z nim Nowe Przymierze, oparte na miłosierdziu Bożym i przypieczętowane ofiarą z własnej krwi: „Ten kielich jest Nowym Przymierzem we Krwi mojej” (1 Kor 11,25). Według Girarda ów mord założycielski dał początek chrześcijaństwu. Powstanie każdej kultury można zawdzięczać pierwotnemu morderstwu dokonanemu dla dobra wspólnoty i opartemu na mechanizmie mimetycznym. U źródeł kultury tkwi rzeczywista ofiara oraz rzeczywista kolektywna przemoc ${ }^{31}$. Tezę tę potwierdza działanie Kajfasza: „Właśnie Kajfasz polecił Żydom, że warto, aby jeden człowiek zginął za naród" (J 18,14). Równie słuszne wydaje się w tym miejscu odwołanie do pracy Totem i tabu Zygmunta Freuda i jego koncepcji powstania kultury opartej na mordzie założycielskim, w której stojący na czele hordy pierwotnej ojciec zostaje zamordowany, a następnie zjedzony, przez swoich synów. Przyczyną mordu jest zawiść i rywalizacja o kobiety, czyli jakby chciał Girard - rywalizacja zrodzona z pragnienia lub raczej pożądania mimetycznego. Przed śmiercią ojciec stworzył surowe prawa, które zabraniały zabijania i kazirodztwa. Po jego śmierci synowie internalizują zakazy ojca i w ten sposób oddają mu cześćc ${ }^{32}$. Podobna sytuacja ma miejsce w Nowym Testamencie. Morderstwo Jezusa spowodowało, że zaczęto Go czcić na skalę masową. Jego śmierci towarzyszy zaćmienie słońca i trzęsienie ziemi - symbolika tak oczywista i głęboko zakorzeniona w każdej kulturze, iż nikogo nie dziwi, że właśnie w tej chwili wielu zaczyna wierzyć w Jego boskie pochodzenie: „Prawdziwie, Ten był Synem Bożym” (Mt 27,54).

$$
* * *
$$

${ }^{31}$ Por. R. Girard, Początki kultury, dz. cyt., s. 88 oraz tenże, Koziol ofiarny, dz. cyt., s. 42.

${ }^{32}$ Z. Freud, Totem i tabu, w: Czlowiek, religia, kultura, dz. cyt., s. 127. 
Pragnienie Prawdy, choć z pozoru wydaje się czymś jednostkowym, nigdy nie może uwolnić się od obecności innego. To inny, a zwłaszcza ten wyjątkowy inny, jak Platoński anax, Mojżesz czy Chrystus, sprawiają, że odczuwamy wieczne niezaspokojenie pragnienia. Ów konstytutywny dla pragnienia brak zawdzięczamy obecności pośrednika pragnienia, co sprawia, że nie jest nam ono bezpośrednio dostępne. Dlatego też poznanie Prawdy jest możliwe jedynie na drodze poznania rozumowego i tylko nielicznym dane jest poznać Ją ,twarzą w twarz". Wyjątkowość wybrańców rodzi zawiść innych, którzy pragną poznać Prawdę nie dla Niej samej, ale dlatego że w Jej poznaniu widzą inne korzyści dla siebie. Tak rozpoczyna się walka o władzę zrodzona z rywalizacji mimetycznej. Pragnienie mimetyczne jest nie tylko pragnieniem zapośredniczonym, ale mechanizmem, który w decydujący sposób wpływa na życie wspólnoty. Platon i Stary Testament nie dopuszczają do wybuchu przemocy mimetycznej: ich wyjątkowi inni, którzy poznali Prawdę, nie zostają zabici, choć groźba mordu jest nieustannie obecna. Thumienie przemocy zrodzonej z pragnienia mimetycznego prowadzi do uformowania wspólnoty opartej na surowym prawie. Jest to kultura zakazów: idealne państwo Platona to państwo o potencjale totalitarnym, w którym zakazuje się „wolnej myśli”. Wspólnota starotestamentowa to państwo religijne zbudowane na zakazach Dekalogu i surowym wizerunku Boga każącego. Różnicę między traktowaniem prawa w Starym i Nowym Testamencie definiuje Jan: „Prawo zostało nadane przez Mojżesza, łaska i prawda przyszły przez Jezusa Chrystusa" (J 1,17). To Chrystus nadaje pragnieniu Prawdy inny kierunek: nie jest to nieświadome pragnienie mimetyczne, lecz pragnienie oparte na świadomym naśladownictwie, a najważniejszym przykazaniem staje się przykazanie miłości. Ofiarnicza śmierć Jezusa przyczynia się do powstania kultury opartej nie na zakazach, lecz na przykazaniu miłości. To z miłości Jezus zsyła Ducha Świętego, czyli Ducha Prawdy (J 14,17). Zabójstwo Jezusa prowadzi do rozładowania przemocy w ofiarniczej katharsis, a więc oczyszcza wspólnotę i stwarza iluzję zażegnania konfliktu. Nowotestamentowa wspólnota, w przeciwieństwie do Platońskiej i starotestamentowej, staje się paradoksalnie wspólnotą miłości bliźniego opartą na mordzie założycielskim.

The DeSire For truth: Plato's PROPOSAL AND THE BIBLICAL CONTEXT IN THE LiGHT OF RENÉ GIRARD'S MIMETIC THEORY AND THE SCAPEGOAT MECHANISM

\section{Summary}

The paper discusses the issue of the desire for truth in Plato's Republic, Book VII, and the Old and New Testaments with regard to Girard's theory of mimetic desire, 
the scapegoat mechanism and the founding murder. Both Plato and the Bible describe outstanding individuals - Anax, Moses and Jesus - who attain truth. This causes communal envy, leading to the outbreaks of mimetic violence. However, neither Plato nor the Old Testament allow the founding murder to happen. Consequently, they depict communities which deal with strict laws and suppressed violence. It is only in the New Testament that mimetic violence finds its outlet in the sacrificial killing of Jesus Christ.

Keywords: Plato; the Old and New Testaments; mimetic desire; scapegoat; the funding murder

Słowa kluczowe: Platon; Stary i Nowy Testament; pragnienie/ pożądanie mimetyczne; kozioł ofiarny; mord założycielski

\section{BIBLIOGRAFIA}

Biblia Tysiaclecia, red. K. Dynarski, Poznań, Warszawa 1989.

Freud Z., Mojżesz i monoteizm, w: Człowiek, religia, kultura, thum. J. Prokopiuk, Warszawa 1967, s. $199-233$.

Freud Z., Totem i tabu, w: Człowiek, religia, kultura, thum. J. Prokopiuk, Warszawa 1967, s. 25-146. Girard R., Kozioł ofiarny, tłum. M. Goszczyńska, Łódź 1991.

Girard R., Początki kultury, tłum. M. Romanek, Kraków 2006.

Girard R., Widziatem szatana padajacego z nieba jak błyskawica, tłum. E. Burska, Warszawa 2002.

Lévinas E., Całość i nieskończoność. Esej o zewnętrzności, thum. M. Kowalska, Warszawa 1998.

Lévinas E., O Bogu, który nawiedza myśl, tłum. M. Kowalska, Kraków 2008.

Platon, Fedon, thum. W. Witwicki, Warszawa 1958.

Platon, Platona Państwo z dodatkiem siedmiu ksiag „Praw”, t. 1, tłum. W. Witwicki, Warszawa 1958.

Agnieszka Gotchold - w 2016 r. obroniła doktorat z wyróżnieniem na Wydziale „Artes Liberales” Uniwersytetu Warszawskiego. Swoją rozprawę doktorską, napisaną w języku angielskim, poświęciła recepcji mitu o Narcyzie w kulturze i literaturze Zachodu, łącząc perspektywę literaturoznawczo-kulturoznawczą z psychoanalizą freudowsko-lacanowską. W kręgu jej zainteresowań naukowych znajdują się m.in.: komparatystyka literacka, psychoanaliza, teoria i recepcja mitów oraz filozofia kultury. Wydała dwie książki: Interdisciplinarity: A Travel through Cultures (2013) oraz The Myth of Narcissus and its Reception in Western Culture: Narcissistic Desire as a Myth of Self-Knowledge (2016). 